\title{
BRD4-Interacting Chromatin-Remodeling Complex-Associated Protein-Like
}

National Cancer Institute

\section{Source}

National Cancer Institute. BRD4-Interacting Chromatin-Remodeling Complex-Associated Protein-Like. NCI Thesaurus. Code C157088.

BRD4-interacting chromatin-remodeling complex-associated protein-like (1079 aa, 115 $\mathrm{kDa}$ ) is encoded by the human BICRAL gene. This protein is involved in SWI/SNFmediated chromatin remodeling. 